\title{
Determining Critical Success Factors that Contribute to the Delay of Water Infrastructure Construction Projects in the Abu Dhabi Emirtae: A Conceptual Framework
}

\author{
Jaafer Y. Altarawneh $^{1}$, Vinesh Thiruchelvam ${ }^{2} \&$ Behrang Samadi $^{1}$ \\ ${ }^{1}$ Faculty of Business and Management, Asia Pacific University of Technology and Innovation (A.P.U), Malaysia \\ ${ }^{2}$ Faculty of Computing, Engineering and Technology, Asia Pacific University of Technology and Innovation \\ (A.P.U), Malaysia \\ Correspondence: Jaafer Y. Altarawneh, Faculty of Business and Management, Asia Pacific University of \\ Technology and Innovation (A.P.U), Malaysia.
}

Received: October 20, 2017

doi:10.5539/ibr.v10n12p139

\author{
Accepted: November 6, $2017 \quad$ Online Published: November 8, 2017 \\ URL: https://doi.org/10.5539/ibr.v10n12p139
}

\begin{abstract}
The purpose of this study is to investigate the relationship between the critical success factors and the critical delays in the context of water infrastructure construction projects (WICPs) in the Abu Dhabi Emirate. In addition, the purpose of this paper is to develop a conceptual model to investigate the potential relationship. The literature concerning the critical success and delay factors and the related models that are available provide a starting point for developing the conceptual model. Based on the comprehensive and thorough literature review, all the dimensions of the variables are identified and discussed in detail.

This study attempts to reduce the existing gap in the literature regarding the relationship between the critical success factors and critical delay. It forms a foundation upon which further local research can be conducted. In addition, it attempts to identify and point out the most critical success factors that will minimize the delay claims in water infrastructure construction projects (WICPs), as such delays would lead to some of the most difficult and controversial disputes to resolve. Internationally, it is expected that the findings of this research may help as an evidentiary reference data on which other and further similar comparative researches could be initiated and developed in different environments in terms of cultural, social, contractual, political, and environmental mediums.

Finally, the conceptual framework was developed by identifying six (6) variables for project critical success namely Project Management Process (PMP), Project Manager Competency (PMC), Project Team Members' Competency (PTC), Project Organizational Planning (POP), Project Resources' Utilization (PRU) and Project Organizational Commitment (POC).
\end{abstract}

Keywords: Abu Dhabi, construction delay, construction projects, critical success factors, success factors

\section{Introduction}

The construction industry represents one of the most important sectors and is considered to be one of the main contributors to the socio-economic growth of a country (Elawi, Algahtany \& Kashiwagic, 2016).

The United Arab Emirates is experiencing a rapid growth in all infrastructure fields, including both urban and rural areas (Ali \& Beheiry, 2015). The government of the Abu Dhabi Emirtae, in particular, is progressively allocating large amounts of resources and money to develop its infrastructure throughout its Emirate territory. Infrastructure, including energy, transport, water, power, and ICT, is very important and requires prolonged and sustained investment to provide for a growing population and increased economic activity (Mohsen, B. Akash, Abdo \& O. Akash, 2016).

Although achieving the completion of construction projects on time is a basic requirement, projects are rarely completed as scheduled despite of the use of developed project management resources, and water infrastructure projects are no exception (Rafat \& Ahmed, 2017). The growing rate of delays in project de livery has become a worldwide problem and a major criticism facing the construction industry, including water infrastructure construction projects (Tumi, Omran \& Pakir, 2009). Delays in infrastructure construction projects can be defined 
as the time overrun either by exceeding the specified completion date in the contract agreement or beyond the date that the construction project main parties agreed upon to deliver (Gunduz, Nielsen \& Ozdemir, 2015). Alternatively, delays can be attributed to unexpected uncertainties during the construction phase (Gardezi, S. S., Manarvi, \& Gardezi, S. J., 2014). Motaleb and Kishk (2013) correlated risk to delay and highlighted delay implications on project success.

During the last five years and due to the subject's high importance, several studies have investigated the factors that lead to the successful completion of construction projects; particularly those factors that influence construction project success more than others (Iyer \& Jha, 2006; Toor \& Ogunlana, 2009; Mukhtar, Amirudin, Sofield \& Mohamad, 2016; Chou, Irawan \& Pham, 2013; Yong \& Mustaffa, 2013; Doloi, Sawhney, Iyer \& Rentala, 2012; Chen, W., Chen, T., Lu \& Liu, 2012; Ahadzie, Proverbs \& Olomolaiye, 2008; Amade, Ubani, Omajeh \& Njoku, 2015; Gudienėa, Banaitisa, Banaitienėa \& Lopesb, 2013; Tabish \& Jha, 2012). Rockart (1982) was the first to use the term "critical success factors." The term "critical success factors" or CSFs implies that certain elements significantly contribute to or are crucial to the success of a project (cited in Tsiga, Emes \& Smith, 2016). In addition, more attention and focus has been oriented against some special areas or factors that might have a significant impact on project success more than others. "Critical success factors thus are, for any business, the limited number of areas in which results, if they are satisfactory, will ensure competitive performance..." (Rockart, 1982). Since the term was first used, numerous studies have explored CSFs for construction projects (Gunduz \& Yahya, 2015; Gudienè, Banaitis, Podvezko \& Banaitienè, 2014; Tsiga et al., 2016). Hence, to be able to achieve success on a project, one must start by determining the factors that affect project success and cause project failure (Toor \& Ogunlana, 2009).

The purpose of this study is to investigate the effect of critical success factors on the project delay in the Abu Dhabi Emirate water infrastructure construction projects (WICPs).

\section{Identification of the Problem}

WICPs perform a significant component of the existing construction industry in the Abu Dhabi Emirate and are subject to the same difficulties that face other sectors in the construction industry in general (Mohsen et al., 2016).

Like other construction sectors, water infrastructure construction projects in the Abu Dhabi Emirate suffer from the chronic problem of project delay, and, during the last two decades, although many water infrastructure projects were started, a high percentage missed the actual contractual completion dates (Gunduz \& AbuHassan, 2016).

The fact that the infrastructure water construction industry in the Abu Dhabi Emirate suffers the most to meet deadlines necessitates great attention to determine the critical success factors, and it is motivated this study. This research builds on the previous studies by examining the success and delay factors that have already been identified for the construction industry, in general, and examines the success and delay factors in an integrated and combined form to identify which critical success factors are the most effective in avoiding or preventing specific critical delay factors in the context of WICPs in the Abu Dhabi Emirate.

Based on the past three decades, all the construction concerned bodies in this region have agreed that the construction industry is facing grave issues, such as inefficiency, non-performance, and a lack of delay analysis (Memon \& Rahman, 2013). While the importance of the Abu Dhabi Emirate construction sector over the past two decades has witnessed a significant growing level, the lack of finesse within the infrastructure construction supply chain remains a key issue in the industry (Gunduz \& Yahya, 2015). There is strong evidence of uncertainties of performance in the Abu Dhabi Emirate construction projects, a trend that is clearly increasing (Gunduz \& Yahya, 2015). An understanding of the inherent factors impacting these key performance measures is still considered as being under investigation, at least in the Abu Dhabi Emirate context; hence, the present study spots shed on the analysis of construction projects performance in terms of the timely delivery of water infrastructure construction projects.

With this growing volume, the scheduled performance of the Abu Dhabi Emirate water infrastructure construction sector is certainly an important topic for investigation. While several previous studies have investigated and published the critical success factors affecting the construction project performance and schedule, in particular, most of the studies are area specific (Thi \& Swierczek, 2010; Chen et al., 2012; Yong \& Mustaffa, 2013; Alzahrani \& Emsley, 2013; Gudienè et al., 2014; Mukhtar et al., 2016). In addition, the applicability of such research in the Abu Dhabi Emirate water infrastructure construction context still considered unexplored, and there is a strong demand to figure out the attributes that lead to project success, understand the effect of these attributes, and combine them into factors. Thus, the main objectives of this research are to identify 
the various attributes for construction success, to identify the relationship between these attributes using statistical methods, and to predict the impact of these identified attributes on construction success using a model in the Abu Dhabi Emirate water infrastructure construction sector.

This study is expected to provide organizations involved in WICPs in the Abu Dhabi Emirate with a solid and useful foundation upon which such strategies concerning how to avoid or prevent delays can be established in the future. This study focuses on water infrastructure construction projects in the Abu Dhabi Emirate. Also, it will assess the critical delay factors, and investigate the relationship between the critical success factors and critical delay to develop the performance of the Abu Dhabi Emirate WICPs against delays by identifying the most critical success factors.

\section{Justification for the Study}

The study focuses on the effect of the critical success factors on the critical delays in the context of WICPs in the Abu Dhabi Emirate. The main rationale for the selection of this area of research is the role that the water infrastructure construction industry plays in the ongoing development of the Abu Dhabi Emirate in line with its 2030 vision to diversify economic resources through the development of the infrastructure of industrial zones, residential areas, shopping facilities, trading centres, housing compounds, and many others.

For every finished WICP in the Abu Dhabi Emirate, a number of deficiencies or delays have occurred (Ali \& Beheiry, 2015), and continue to occur. It has been observed that the delays in WICPs in the Abu Dhabi Emirate have increased considerably in the last ten years and the government, at present, is spending billions of dollars, and it is expected that more money will be invested in this sector. Occasionally, new difficulties develop, and, despite the serious efforts to put into action every success measure, these problems persist (Motaleb \& Kishk, 2013). Similar problems are notified in the status of numerous WICPs.

While a body of research exists that recognizes the main reasons behind project delays, and further literature points out a wide range of success factors in the construction industry, in general, and in different countries, no research was found that illustrates the influence of critical success factors on the critical delay in WICPs, and how knowledge of this interplay might facilitate the completion of more successful projects (Mukhtar et al., 2016; Gunduz \& AbuHassan, 2016; Amade et al., 2015; Gudiene et al., 2013). This study is also the first of its kind to explore and rank the effect of the critical success factors in a trial to help the project parties involved in WICPs prevent or avoid critical delays.

Mukhtar et al. (2016) and Chen et al. (2012) concluded from the existing empirical studies on the influence of the critical success factors on project performance in terms of delays that targeted the general construction industry in the researcher's country that further investigation in different countries/areas is necessary due to the localized nature of the construction industry. Thus, it is expected that this study will contribute by providing useful information by investigating this issue in different countries and filling the gap related to the specific type of construction industry in de veloping Arab countries in the Middle East, and, in particular, in the UAE in the Abu Dhabi Emirate.

Furthermore, an important contribution of this research relies on the significance of the selected industry - the water infrastructure industry - due to the significant and critical role of this industry on many levels (Mohsen et al., 2016). Thus, the results of this study will be useful to various stakeholders and make several contributions. For the government, development partners, project managers, consultants, contractors and clients in the water sector, the study will clarify the relationship between CSFs and project delay as an indicator of project performance. Through this, the project participants, including the main players, such as project managers, are expected to adopt appropriate procedures that will enhance project performance in the water sector.

With enhanced project performance in the water sector, it is expected that the study findings will result in value for money, and, hence, reduce the wastage of public funds through a reduction in the delay and associated cost over-runs. Accordingly, this would enable the government to channel saved resources to other sectors of the economy or to start more projects. In addition, the study findings are expected to spur social-economic development in the country through the provision of affordable and sustainable water services to its industries and citizens.

There is limited research concerning the strength of the relationship between the critical factors and the success criteria, and there is even less analysis of the relationship between these factors and the performance of projects in Asia in terms of delay. Key construction project factors need to be identified as successful by consider the level of performance accomplished in a several real projects (Thi \& Swierczek, 2010).

The Abu Dhabi Emirate don't have empirical research in this area of study, and this study is the first of its type to 
check into thoroughly the main success factors for the success of WICPs in the Abu Dhabi Emirate. This research forms a platform upon which further local research can be performed. In addition, it attempts to identify the most critical success factors that will minimize delays in WICPs as such delays lead to some of the most difficult and controversial disputes to resolve. Internationally, it is expected that the findings of this study may help as an evidentiary reference data on which other and further similar studies could be initiated and developed in different environments in terms of cultural, social, contractual, political, and environmental mediums.

\section{Literature Review}

\subsection{Most Common Critical Delays}

From the presented literature review and many other studies, five (5) factors were identified as common in different geographical areas and for various types of construction industry (Elawi et al., 2016; Marzouk \& El-Rasas, 2014; Gunduz \& AbuHassan, 2016; Frimpong, Oluwoyeb \& Crawford, 2003; Motaleb \& Kishk, 2013; Aziz \& Abdel-Hakam, 2016; Durdyev, Omarov \& Ismail, 2017; Alzaraa, Kashiwagib, Kashiwagic \& Al-Tassand, 2016; Gonzalez, P., Gonzalez, V., Molenaar \& Orozco, 2013).

However, due to the similarity in their economic position, weather conditions, cultural mode, and several other issues, the delay attributes shared among the Gulf community countries were given the most weight in selecting the critical delay factors. The selected five delay factors are:

(1) change in scope, design, and specifications,

(2) material problems,

(3) financial difficulties (cash flow),

(4) poor productivity/non-availability of labour, and

(5) poor communication and coordination among parties.

\subsection{Critical Success Factors (CSFs)}

The CSF implies certain elements that significantly contribute to, and are vital to the success of a project (Rockart, 1982). Therefore, to be able to achieve project success, one must start by determining those factors that affect project success and cause project failure (Toor \& Ogunlana 2009). This study refers to the six factors project management process, project manager's competency, project team member's competency, project organizational planning, project resources utilization, and project organizational commitment - that enable project organizations to achieve better performance.

\subsubsection{Project Management Process (PMP)}

The project management process consists of acceptable level of funding through the project including incentives and motivation (Gudienè et al., 2014). These ensure that construction projects run smoothly (Gudienè et al., 2014). Money and other resources in terms of continuous funding through on time payments until project completion are obviously imperative for the successful completion of projects $(\mathrm{Ng}$, Tang \& Palaneeswaran, 2009; Marzouk \& El-Rasas, 2014; Gudienè et al., 2013). Proper emphasis on the past experience and qualifications of the awarded contractors through strict prequalification procedures are among the success factors proposed in many textbooks and previous research works (Alzahrani \& Emsley, 2013). In addition, a very clear project scope will eliminate any ambiguity in the way the project progresses to achieve the desired outcomes (Jha \& Iyer, 2006; Doloi et al., 2012; Gudiene et al., 2013; Ihuah, Tippett \& Eaton, 2014; Chan et al., 2004). However, it is highlighted that the need to conduct proper site investigation prior to establishing the scope would play a critical role in determining the most fit scope of work (Ihuah, Tippett \& Eaton, 2014; Ng, Wong, Y. \& Wong, J., 2012).

Proposition 1. PMP has a significant effect on critical delay.

\subsubsection{Project Manager Competency (PMC)}

Project managers (PMs) are the key people in the projects (Tabish \& Jha, 2012). They show multi-dimensional skills and capacities including interpersonal, technical, and administrative skills (Fortune \& White, 2006; Gudiene et al., 2013; Thuah et al., 2014). The most important element is that PMs understand clearly their function as project leaders; clearly defining their magnitude level of involvement, and the authority and control, they practice over personnel. According to several researchers (Gudiene et al., 2013; Nguyen, Ogunlana \& Lan, 2004; Tabish \& Jha, 2012; Toor \& Ogunlana, 2009), the main competency fields of the project manager are capability in terms of the proper technical background that encourages respect from team players, technical experience, coordinating, mutual trust and understanding, and decision-making effectiveness. 
Proposition 2. PMC has a significant effect on critical delay.

\subsubsection{Project Team Members' Competency (PTC)}

Several researchers highlighted the capabilities that members possess in general, including capacities and experience, hold on appropriate interpersonal skills, coordination skills and a good working relationship with the owner, the project team members (PTM) and the stakeholders, and maintain a healthy work attitude (P.C.Chan, Scott \& P.L.Chan, 2004; Gudiene et al., 2013; Ihuah et al., 2014; Jha \& Iyer, 2006; Tabish \& Jha, 2012; Yang, Huang \& Wu, 2011). Furthermore, Famakin et al. (2012) and Gudienė et al. (2013) pointed out PTMs responsibilities for organizing, appointing and illustrating the responsibilities of the project resources. Also, according to Toor and Ogunlana (2009), monitoring the achievements, classifying problems, communicating the status of interfaces to participants, and initiating and co-coordinating remedy action come under the responsibilities of PTMs. Toor and Ogunlana (2009) and Gudienè et al (2014) opined that project team members capabilities include make effective decisions, and convince the project participants to cooperate with each other guided by the proper troubleshooting of project related issues (Toor \& Ogunlana, 2009; Ismail, Yusuwan \& Baharuddin, 2012; Gudienè et al., 2014).

Proposition 3. PTC has a significant effect on critical delay.

\subsubsection{Project Organizational Planning (POP)}

From the literature, the factors relating to the project organization planning include top management decisions and support, delegation and allocation of authority and responsibility, effective well-established information and communication routines, effective budget controlling, and adequate management of resources ( $\mathrm{Ng}$ et al., 2009; Gudiene et al., 2013; Alzahrani \& Emsley, 2013). Thi and Swierczek (2010) remarked that one of the significant critical factors for the successful completion of projects is top management support. Support is usually strongest if there is proper delegation and allocation of authority and responsibility (Thi \& Swierczek, 2010; Chen et al., 2012). Top management support depends on the effective communication channels in which the information flow facilitates the provision of the proper resources under the umbrella of effective budget controlling measures (Ogwueleka, 2011; Chen et al., 2012).

Proposition 4. POP has a significant effect on critical delay.

\subsubsection{Project Resources' Utilization(PRU)}

This factor includes the utilization of up-to-date technology, ensuring and controlling the quality of all the activities of the construction works, adequate resources and proper allocation resources, and awarding bids to the right designer/contractor ( $\mathrm{Ng}$ et al., 2009). Construction projects need particular types of technology; howe ver, selecting the proper technology may be problematic, especially when there is no right allocation of resources (Fortune \& White, 2006; Chan et al., 2004). A serious challenge to the construction industry in developing countries, due to the lack of transparency, is their inability to adopt or adapt established best practices in terms of the quality standards and prequalification programmes (Babatunde, Olusegun \& Akinsiku, 2012; Abdul-Aziz \& Kassim, 2011; Ng et al., 2009; Ling \& Bui, 2010; Gudienè et al., 2013;Yong \& Mustaffa, 2013; Gudienė et al., 2014).

Proposition 5. PRU has a significant effect on critical delay.

\subsubsection{Project Organizational Commitment (POC)}

Commitment is broadly considered to be an important factor for the success of projects. It is a critical sign that all the project members and people involved are strongly interested in the project (Chan et al., 2004; Tabish \& Jha, 2012; Yang et al., 2012; Yong \& Mustaffa, 2013). Some researchers highlighted the role of the participants to understand, and how dedicated and strongly committed to achieve, maintain and fulfil the project goals (Jha \& Iyer, 2006; Tabish \& Jha, 2012). Other researchers remarked the participants' commitment to the concept of project planning and control, and how to be able to put the concept into practice (Jha \& Iyer, 2006; Thi \& Swierczek, 2010). Furthermore, they highlighted the importance of project participants understanding of the project management process, its purpose and value, and be committed to the necessary procedures (Jha \& Iyer, 2006; Thi \& Swierczek, 2010).

According to some researchers, commitment factor is made up of owner commitment to the approval and payment method, commitment to the goals/objectives, commitment to the quality standards and owner's standards, commitment to safety, and the prevention of accidents and hazards, and commitment to zero variation orders (Gudienè et al., 2014; Chen et al., 2012; Doloi et al., 2012; Alzahrani \& Emsley, 2013; Cserháti \& Szabó, 2014).

Proposition 6. POC has a significant effect on critical delay. 


\section{Conceptual Framework}

Understanding the significance and importance of each success factor will facilitate the formulation of CSFs for WICPs in the Abu Dhabi Emirate. Therefore, a consolidated framework of critical success factors has been suggested based on the analysis of the review. After a review of the relevant literature and the formulation of the conceptual research framework, the conceptual model was de veloped which shows the relationships among the variables.

The model of hypothesized relationships between the critical success factors and critical delay in WICPs in the Abu Dhabi Emirate is presented diagrammatically in Figure 1. The six factors appear in the model depict the exogenous variables (independent variables), while the critical delay is the endogenous variable (dependent variable). In each of the relationships, a line has been drawn with a single arrowhead starting from each of the factors pointing towards the critical delay, which indicates a direct positive association. The effect of each group with common interest is estimated by the parameters linking a critical success factor and critical delay (P1-P6), which displays the amount of change in the endogenous variable as a result of a unit change in the exogenous variable (Kline, 2011). For instance, the project management process (PMP) is hypothesized to have an effect on the critical delay. Thus, an arrow starts from the project management process (PMP) factor to the critical delay. In the same manner the other five factors - project manager's competency (PMC), project team members' competency (PTC), project organizational planning (POP), project resources' utilization (PRU) and project organizational commitment (POC) - are hypothesized to have an effect on the critical delay.

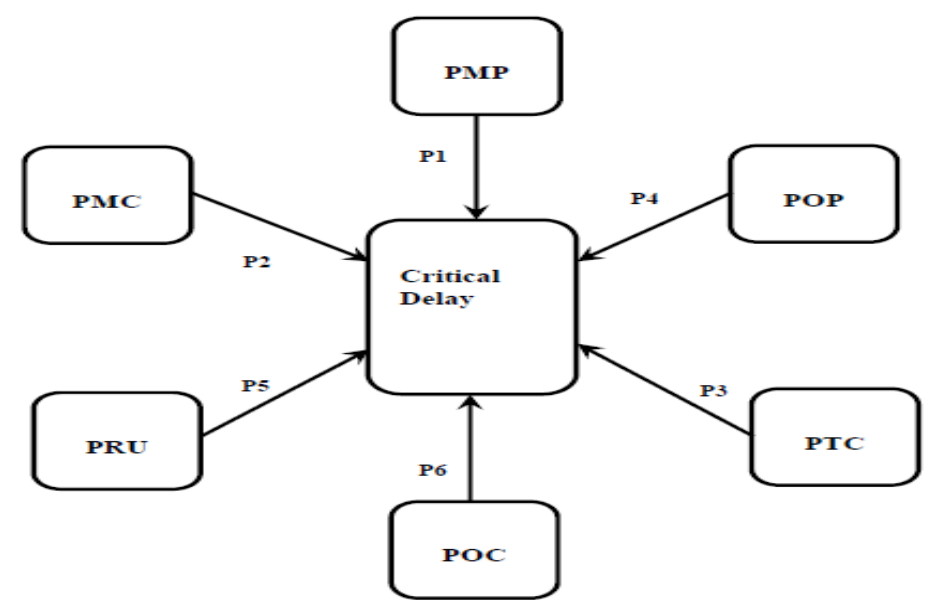

Figure 1. Conceptual framework

\section{Discussion}

The problems facing the construction industry have a negative impact on construction projects, in general, and, ultimately, affect the economy as a whole (Motaleb \& Kishk, 2013). Hence, this research investigates these problems in the context of water infrastructure projects in the Abu Dhabi Emirate in order to highlight the importance of the success factors that could avoid or eradicate the delay factors that affect WICPs in the Abu Dhabi Emirate. The research proposes that simply applying critical success factors or taking the necessary precautions might not be enough to enable the partners in the Abu Dhabi Emirate water infrastructure construction projects to avoid or prevent critical delay factors mainly during the construction. Further research to investigate the interrelationship between critical success and the critical delay factors will help the concerned bodies in the Abu Dhabi Emirate water infrastructure construction projects, including the developers, contractors, and consultants, to determine which factors would deserve high attention and accordingly provide the most effective measures to avoid or prevent critical delay.

\section{Conclusion}

The main goal of this research is to improve the efficiency of WICPs in the Abu Dhabi Emirate by pre venting or avoiding delays and enhancing the success in the delivery of WICPs by investigating the effect of the critical success factors on critical delays. This research develops a conceptual framework to investigate the relationship between CSFs and critical delay from the perception of the main participants of WICPs.

This study makes effort to reduce the existing gap in the literature regarding the relationship between the critical 
success factors and critical delay. It establishes a solid ground upon which further future local study can be administered. In addition, it attempts to determine the most critical success factors that will minimize the claims for delay in WICPs, as delays would lead to some of the most difficult and controversial disputes to resolve.

\section{References}

Abdul-Aziz, A., \& Kassim, P. (2011). Objectives, success and failure factors of housing public private partnerships in Malaysia. Habitat international, 35, 150-157. https://doi.org/10.1016/j.habitatint.2010.06.005

Aftab, H. M., \& Ismail, A. R. (2013). Analysis of Cost Overrun Factors for Small Scale Construction Projects in Malaysia Using PLS-SEM Method. Modern Applied Science, 7(8).

Ahadzie, D. K., Proverbs, D. G., \& Olomolaiye, P. O. (2008). Critical success criteria for mass house building projects in developing countries. International Journal of Project Management, 26, 675-687. https://doi.org/10.1016/j.ijproman.2007.09.006

Albert, P. C. C., David, S., \& Ada, P. L. C. (2004). Factors affecting the success of construction project through a conceptual framework. Journal of Const: Engg: and management, 130, 150-155.

Alzahrani, J., \& Emsley, M. (2013). The impact of contractors' attributes on construction project success: A post construction evaluation. International Journal of Project Management, 31, 313-322. https://doi.org/10.1016/j.ijproman.2012.06.006

Amaka, O. (2011). The critical success factors influencing project performance in Nigeria. International Journal of Management Science and Engineering Management, 6(5), 343-349.

Benedict, A., Emmanuel, C. U., Enoch, O. M. O., \& Uchenna, A. P. N. (2015). Critical Success Factors for Public Sector Construction Project Delivery: A Case of Owerri, Imo State. International Journal of Research in Management, Science \& Technology, 3(1). (E-ISSN: 2321-3264).

Cao, H. T., \&Fredric, W. S. (2010). Critical success factors in project management: implication from Vietnam. Asia Pacific Business Review, 16(4), 567-589. https://doi.org/10.1080/13602380903322957

Chou, J., Irawan, N., \& Pham, A. (2013). Project management knowledge of construction professionals: cross-country study of effects on project success. Journal of construction engineering and management, 0733-9364. https://doi.org/10.1061/(ASCE)CO.1943-7862.0000766

Cserháti, G., \& Szabó, L. (2014). The relationship between success criteria and success factors in organisational event projects. International Journal of Project Management, 32, 613-624. https://doi.org/10.1016/j.jproman.2013.08.008

Famakin, Aje, I. O., \& Ogunsemi, D. R. (2012). Assessment of success factors for joint venture construction projects in Nigeria. Journal of Financial Management of Property and Construction, 17(2), 153-165. https://doi.org/10.1108/13664381211246606

Farhan, R., \& Riaz, A. (2017). Empirical Study on Causes of Project Delays. World Academy of Science, Engineering and Technology, 11(1), 2017. Retrieved from http://scholar.waset.org/1307-6892/10006253

Fortune, J., \& White, D. (2006). Framing of project critical success factors by a systems model. International Journal of Project Management, 24, 53-65. https://doi.org/10.1016/j.ijproman.2005.07.004

Gardezi, S. S. S., Manarvi, I. A., \& Gardezi, S. J. S. (2014). Time Extension Factors in Construction Industry of Pakistan. Procedia Engineering, 77, 196-204. https://doi.org/10.1016/j.proeng.2014.07.022

Ghazi, S. A. E., Mohammed, A., \& Dean, K. (2016). Owners' perspective of factors contributing to project delay: case studies of road and bridge projects in Saudi Arabia. International Conference on Sustainable Design, Engineering and Construction, Procedia Engineering, 145, 1402-1409. https://doi.org/10.1016/j.proeng.2016.04.176

Gonzalez, P., Gonzalez, V., Molenaar, K., \& Orozco, F. (2013). Analysis of Causes of Delay and Time Performance in Construction Projects: Journal of Construction Engineering and Management, ASCE, 04013027, 1-9.

Gunduz, M., Nielsen, Y., \& Ozdemir, M. (2015). Fuzzy assessment model to estimate the probability of delay in Turkish construction projects. Journal of Management in Engineering, 31(4), 04014055. https://doi.org/10.1061/(ASCE)ME.1943-5479.0000261

Hemanta, D., Anil, S., \& Iyer, K. C. (2012). Structural equation model for investigating factors affecting delay in 
Indian construction projects. Construction Management and Economics, 30(10), 869-884. https://doi.org/10.1080/01446193.2012.717705

Ihuah, P., Tippett, W., \& Eaton, D. (2014). A review of critical project management success factors (CPMSF) for sustainable social housing in Nigeria. International journal of sustainable built environment, 3, 62-71. https://doi.org/10.1016/j.ijsbe.2014.08.001

Ismail, F., Yusuwan, N., \& Baharuddin, H. (2012). Management Factors for Successful IBS Projects Implementation. Planning and Surveying, University Technology in Malaysia. ASIA Pacific international conference on environment-behaviour studies Mercure Le Sphinx Cairo hotel, Giza, Egypt, 31 October 2 November 2012. Procedia Social and Behavioral Sciences: Malaysia, 68, 99-107. https://doi.org/10.1016/j.sbspro.2012.12.210

Iyer, K., \& Jha, K. (2006). Critical factors affecting schedule performance: evidence from Indian construction projects. Journal of construction engineering and management, 132(8), 871-881. https://doi.org/10.1061/(ASCE)0733-9364(2006)132:8(871)

Kline, R. B. (2011). Principles and practice of structural equation modeling, 3rd edition. Guilford Press, New York

Ling, F., \& Bui, T. (2010). Factors affecting construction project outcomes: case study of Vietnam. Journal of professional issues in engineering education and practice, 136(3), 148-155. https://doi.org/10.1061/(ASCE)EI.1943-5541.0000013

Majed, A., Jacob, K., Dean, K., \& Abdulrahman, A. T. (2016). Using PIPS to minimize causes of delay in Saudi Arabian construction projects: university case study. International Conference on Sustainable Design, Engineering and Construction. Procedia Engineering, 145, 932-939. https://doi.org/10.1016/j.proeng.2016.04.121

Mohamed, A., \& Salwa, B. (2015). The Applicability Of Just-In-Time In United Arab Emirates Construction Projects. Journal of Emerging Trends in Engineering and Applied Sciences, (ISSN: 2141-7016), 120-128.

Mohamed, M. M., \& Tarek, I. E. (2014). Analyzing delay causes in Egyptian construction. Journal of Advanced Research, 5, 49-55. https://doi.org/10.1016/j.jare.2012.11.005

MOTALEB, O., \& KISHK, M. (2013). An investigation into the risk of construction project delays in the UAE. International Journal of Information Technology Project Management, 4(3), 50-65. https://doi.org/10.4018/jitpm.2013070104

Mousa, S., Mohsen, B. A., Ahmed, A. A., \& Omar, A. (2016). Energy Options for Water Desalination in UAE. The 6th International Conference on Sustainable Energy Information Technology (SEIT 2016). Procedia Computer Science, 83, 894-901.

Murat, G., \& Ahmad, M. A. Y. (2015). Analysis of project success factors in construction industry. Technological and Economic Development of Economy.

Murat, G., \& Mohanad, H. A. A. (2016). Causes of delay in Qatar construction project. International Journal of Civil, Environmental, Structural, Construction and Architectural Engineering, 10(4). Retrieved from http://scholar.waset.org/1307-6892/10004362

Musa, M. M., Roslan, B. A., Trevor, S., \& Ismail, B. M. (2016). Critical success factors for public housing projects in developing countries: a case study of Nigeria. Environ Dev Sustain.

Neringa, G., Audrius, B., Nerija, B., \& Jorge, L. (2013). Development of a Conceptual Critical Success Factors Model for Construction Projects: a Case of Lithuania. Procedia Engineering, 57, 392-397. https://doi.org/10.1016/j.proeng.2013.04.051

Neringa, G., Audrius, B., Valentinas, P., \& Nerija, B. (2014). Identification and e valuation of the critical success factors for construction projects in Lithuania: AHP approach. Journal of Civil Engineering and Management, 20(3), 350-359. https://doi.org/10.3846/13923730.2014.914082

Ng, S., Tang, Z., \& Palaneeswaran, E. (2009). Factors contributing to the success of equipment intensive subcontractors in construction. International journal of project management, 27, 736-744. https://doi.org/10.1016/j.ijproman.2008.09.006

Ng, S., Wong, Y., \& Wong, J. (2012). Factors influencing the success of PPP at feasibility phase: a tripartite comparison study in Hong Kong. Journal of habitat international, 36, 423-432. https://doi.org/10.1016/j.habitatint.2012.02.002 
Nguyen, L., Ogunlana, O., \& Lan, D. (2004). A study on project success factors in large construction projects in Vietnam. Journal of engineering construction and architectural management, 11(6), 404-413. https://doi.org/10.1108/09699980410570166

Remon, F. A., \& Asmaa, A. A. (2016). Exploring delay causes of road construction projects in Egypt. Alexandria Engineering Journal, 55, 1515-1539. https://doi.org/10.1016/j.aej.2016.03.006

Rockart, J. F. (1982). The changing role of the information system executive: a critical success factor perspective. MIT Sloan Management Review, 23(3), 3-13.

Saleh, A. H. T., Abdelnaser, O., \& Abdul, H. K. P. (2009). CAUSES OF DELAY IN CONSTRUCTION INDUSTRY IN LIBYA. The International Conference on Administration and Business.

Serdar, D., Maksat, O., \& Syuhaida, I. (2017). CAUSES OF DELAY IN RESIDENTIAL CONSTRUCTION PROJECTS IN CAMBODIA. Cogent Engineering.

Shamas-ur-Rehman \& Toor, S. O. O. (2009). Construction professionals' perception of critical success factors for large-scale construction projects. Construction Innovation, 9(2), 149-167. https://doi.org/10.1108/14714170910950803

Solomon, O. B., Akintayo, O. O., \& Emmanuel, A. (2012). Critical success factors in public private partnership (PPP) on infrastructure delivery in Nigeria. Journal of Facilities Management, 10(3), 212-225. https://doi.org/10.1108/14725961211246018

Tabish, S. Z., \& Jha, K. N. (2012). Success traits for a construction project. ASCE Journal of Construction Engineering and Management, 138(10), 1131-1138. https://doi.org/10.1061/(ASCE)CO.1943-7862.0000538

Wei, T. C., Tung-Tsan, C., Chun, S. L., \& Shu-Shun, L. (2012). Analyzing relationships among success variables of construction partnering using structural equation modeling: a case study of Taiwan's construction industry. Journal of Civil Engineering and Management, 18(6), 783-794. https://doi.org/10.3846/13923730.2012.735062

Yang, L., Huang, J., \& Wu, K. (2011). The association among project manager's leadership style, teamwork and project success. International journal of project management, 29, 258-267. https://doi.org/10.1016/j.ijproman.2010.03.006

Yaw, F., Jacob, O., \& Lynn, C. (2003). Causes of delay and cost overruns in construction of groundwater projects in a de veloping countries; Ghana as a case study. International Journal of Project Management, 21, 321-326. https://doi.org/10.1016/S0263-7863(02)00055-8

Yee, C. Y., \& Nur, E. M. (2013). Critical success factors for Malaysian construction projects: an empirical assessment. Construction Management and Economics, 31(9), 959-978. https://doi.org/10.1080/01446193.2013.828843

Zakari, T., Michael, E., \& Alan, S. (2016). Critical Success Factors For The Construction Industry. PM World Journal, $V(\mathrm{VIII})$.

\section{Copyrights}

Copyright for this article is retained by the author(s), with first publication rights granted to the journal.

This is an open-access article distributed under the terms and conditions of the Creative Commons Attribution license (http://creativecommons.org/licenses/by/4.0/). 